\title{
Pembelajaran Mendalam untuk Membentuk Karakter Siswa sebagai Pembelajar
}

\author{
Moh. Khoerul Anwar \\ Universitas Islam Negeri Sunan Kalijaga; moh.anwar@uin-suka.ac.id
}

Diterima: 20 September 2017. Disetujui: 12 November 2017. Dipublikasikan: Desember 2017

\begin{abstract}
This article aims to develop learning methods to establish the character of students as learners. Learning method developed is deep learning to establish the character of students as learners. This research method used document study based on research results and literature review. Deep learning is a learning that leverages the power of new partnerships to engage students in practicing the learning process through discovering and mastering existing knowledge and then creating and using new knowledge in the world so that the outcomes of deep learning seek to increase students' understanding of their strengths and weaknesses, data collection regarding student profile information and trust value building among members of student learning groups.
\end{abstract}

\begin{abstract}
Abstrak
Tujuan dari penulisan ini adalah untuk mengembangkan metode pembelajaran mendalam untuk membentuk karakter siswa sebagai pembelajar. Metode penelitian yang digunakan dalam penulisan ini adalah studi dokumen berbasis hasil penelitian dan kajian literatur. Pembelajaran mendalam merupakan pembelajaran yang memanfaatkan kekuatan kemitraan baru untuk melibatkan para siswa dalam mempraktekkan proses pembelajaran melalui menemukan dan menguasai pengetahuan yang ada dan kemudian menciptakan serta menggunakan pengetahuan baru di dunia sehingga hasil dari pembelajaran mendalam berupaya pada peningkatan pemahaman siswa tentang kelebihan dan kelemahannya, pengumpulan data mengenai informasi profil siswa dan pembangunan nilai kepercayaan diantara anggota kelompok belajar siswa.
\end{abstract}

Kata Kunci: Pembelajaran Mendalam, Karakter, Siswa

() 2017 URPI, FTK UIN Raden Intan Lampung

\section{PENDAHULUAN}

Peningkatan kualitas sumber daya manusia guna mengikuti perkembangan zaman yang pesat dapat dilakukan dengan melakukan peningkatan mutu pendidikan (Eko \& Cahyono, 2017; Latifah, 2015). Saat seseorang lahir ke dunia, ia dibekali dengan berbagai potensi yang harus diaktualisasikan. Proses aktualisasi potensi secara sengaja disebut dengan proses pendidikan (Rukiyati, 2013). Sebagaimana yang diungkapkan oleh Sapulette \& Wardana bahwa pendidikan adalah sebuah wadah untuk membentuk perilaku, potensi, dan karakter seseorang
(Sapulette \& Wardana, 2016; Sukring, 2016).

Upaya meningkatkan kemajuan suatu bangsa, dapat dilakukan dengan peningkatan mutu pendidikan yang berawal dari tujuan pendidikan (Irwandani \& Juariyah, 2016). Pendidikan yang bermutu bertujuan untuk mengembangkan potensi diri, mencakup kecerdasan intelektual dan kepribadian yang positif. Tujuan tersebut dapat dicapai jika dalam pelaksanaannya pemerintah bersama seluruh insan pendidikan saling mendukung untuk menciptakan generasi penerus yang 
unggul dan berkualitas (Eko \& Cahyono, 2017). Selain itu Proses belajar mengajar di kelas dapat mempengaruhi mutu pendidikan karena Pendidikan adalah hal yang terpenting dalam kehidupan seseorang (Irwandani \& Rofiah, 2015; Sari, Farida, \& Syazali, 2016). Namun, kenyataannya saat ini pendidikan cenderung menerapkan ilmu pengetahuan dari pada menerapkan bagaimana agar siswa-siswi di sekolah dapat memahami, mengembangkan karakter serta potensi dirinya (Sapulette \& Wardana, 2016).

Undang-undang No 20 tahun 2003 tentang Sistem Pendidikan Nasional Bab 2 Pasal 3 menyatakan bahwa pendidikan nasional berfungsi mengembangkan kemampuan dan membentuk watak serta peradaban bangsa yang bermartabat dalam rangka mencerdaskan kehidupan bangsa, bertujuan untuk berkembangnya potensi siswa agar menjadi manusia yang beriman dan bertaqwa kepada Tuhan Yang Maha Esa, berakhlak mulia, sehat, berilmu, cakap, kreatif, mandiri, dan menjadi warga negara yang demokratis serta bertanggung jawab (Rahayu, 2016). Dalam hal ini, pendidikan menjadi salah satu bidang yang memiliki peran yang penting dalam membentuk generasi yang cerdas, bijaksana, dan berkarakter (Rachmadyanti, 2017).

Karakter sangat erat dengan perilaku diri seseorang dalam mengembangkan potesi diri untuk dapat berkembang dengan baik (Nashikhah, 2016). Karakter sangat dibutuhkan untuk mencapai keberhasilan suatu pendidikan. Individu yang berkarakter baik adalah individu yang dapat membuat keputusan dan siap untuk mempertanggungjawabkan setiap akibat dari keputusan yang telah dibuat (Suradi, 2017). Oleh karena itu pembangunan karakter bangsa merupakan hal yang amat penting dilaksanakan (Rachmadyanti, 2017).

Pendidikan karakter merupakan upaya-upaya yang dirancang dan dilaksanakan secara sistematis untuk menanamkan nilai-nilai perilaku peserta didik yang berhubungan dengan Tuhan Yang Maha Esa, diri sendiri, sesama manusia, lingkungan, dan kebangsaan yang terwujud dalam pikiran, sikap, perasaan, perkataan, dan perbuatan berdasarkan norma-norma agama, hukum, tata karma, budaya, dan adat istiadat (Diani, 2015). Pendidikan karakter merupakan pendidikan dalam mengatur sikap seseorang untuk mempuyai kepribadian yang bagus. Pendidikan karakter merupakan proses transformasi nilai-nilai, sehingga menghadirkan watak baik (transforming values into virtue). Pendidikan karakter sejak dini pada anak adalah langkah awal dari pembentukan karakter anak sehingga diperlukanya pendidikan sejak awal (Nashikhah, 2016). Pendidikan karakter yang secara sistematis diterapkan dalam kegiatan pembelajaran merupakan daya tawar berharga bagi seluruh komunitas. Para peserta didik mendapatkan keuntungan dengan memperoleh perilaku dan kebiasaan positif yang mampu meningkatkan rasa percaya dalam diri mereka, membuat hidup mereka lebih bahagia dan lebih produktif (Asyhari \& Hartati, 2015).

Pendidikan dan pembelajaran merupakan satu paket yang tak terpisahkan. Pembelajaran merupakan bagian penting dari proses pendidikan. Untuk memiliki kualitas pendidikan yang baik maka perlu konsep pembelajaran yang baik pula. Kegiatan pembelajaran diselenggarakan untuk membentuk watak, membangun pengetahuan, sikap dan kebiasaan-kebiasaan untuk meningkatkan mutu kehidupan peserta didik. Atas dasar itulah pentingnya kegiatan pembelajaran yang memberdayakan semua potensi peserta didik untuk menguasai kompetensi yang diharapkan (Suradi, 2017). Dalam hal ini penulis menggagas sebuah model pembelajaran untuk membentuk karakter siswa sebagai pembelajar. Model pembelajaran yang 
penulis gagas pada penelitian ini adalah model pembelajaran mendalam.

Fullan dan Langworthy mengatakan bahwa pembelajaran mendalam merupakan pembelajaran yang memanfaatkan kekuatan kemitraan baru untuk melibatkan para siswa dalam mempraktekkan proses pembelajaran melalui menemukan dan menguasai pengetahuan yang ada dan kemudian menciptakan dan menggunakan pengetahuan baru di dunia (Fullan \& Langworthy, 2014). Dengan pembelajaran mendalam diharapkan siswa mampu memahami bahwa belajar adalah kebutuhan untuk dirinya dimasa yang akan datang. Secara lebih lanjut, model ini diharapkan mampu memecahkan beberapa masalah yang sedang terjadi di lingkungan pendidikan pada saat ini seperti moralitas, karakter dan motivasi belajar.

Berdasarkan analisis ESQ, ditengarai ada tujuh krisis moral di tengah-tengah masyarakat Indonesia, yaitu: krisis kejujuran, krisis tanggung jawab, tidak berpikir jauh ke depan, krisis disiplin, krisis kebersamaan, krisis keadilan, krisis kepedulian. Sejalan dengan pendapat tersebut, maka pembelajaran mendalam berupaya untuk membentuk karakter siswa sebagai pembelajar (Rukiyati, 2013). Lebih lanjut, Fullan dan Langworthy mengatakan bahwa pembelajaran mendalam meliputi proses pembelajaran praktik, penciptaan pengetahuan baru dan penggunaan pengetahuan baru, kunci keterampilan masa depan dan disposisi proaktif. Barringer menjelaskan bahwa diperlukan kunci untuk mengetahui siswa sebagai pembelajar yakni mengumpulkan data dari berbagai sumber (menilik pembelajaran, menilai pembelajaran) dan data kualitatif yang dikumpulkan dari berbagai sumber memungkinkan untuk melihat berbagai kekuatan, kelemahan, dan kesempatan serta mengidentifikasi pola yang membantu membuat deskripsi kaya siswa sebagai pelajar. Artinya pembelajaran mendalam relevan untuk membentuk karakter siswa sebagai pembelajar. Siswa sebagai pembelajar membutuhkan kunci, yakni diantaranya adalah mampu memahami akan kelebihan dan kekurangan, bakat, potensi dan minat dari masing-masing siswa.

Oleh karenanya, penulis berupaya menggagas pentingnya pembelajaran mendalam guna mengatasi indeks pembangunan manusia yang masih rendah dan berupaya untuk membentuk karakter siswa sebagai pembelajar. Pembelajaran mendalam bersifat membangun manusia semakin mengenal dan memahami dirinya baik bakat, potensi, minat dan kelebihan maupun kelemahannya dengan berkolaborasi berbagai pihak. Pembelajaran mendalam juga berupaya membangun aspek kreativitas, keterampilan dan kepemimpinan dalam pembelajaran. Oleh karenanya, pembelajaran mendalam merupakan salah satu strategi yang penting dalam membentuk karakter siswa sebagai pembelajar.

\section{METODE PENELITIAN}

Pendekatan dalam penulisan ini adalah studi dokumen. Pada penelitian ini penulis mengkaji beberapa literatur baik buku, jurnal, hasil penelitian, maupun data yang berkaitan dengan pembelajaran mendalam. Data yang dikumpulkan untuk dianalisis berdasarakan pada penulisan ini diambil dari buku-buku, jurnal, hasil penelitian, dan prosiding.

Teknik analisis data yang digunakan adalah deskriptif kualitatif, dimana pendekatan ini menfokuskan pada beberapa literatur baik buku, prosiding, jurnal, penelitian maupun lainnya kemudian di analisis sehingga menjadi narasi yang menjelaskan tentang hasil dan kesimpulan dari isi artikel ini. Oleh karenanya, penulisan ini berupa gagasan atau ide terkait pembelajaran mendalam 
untuk membentuk karakter siswa sebagai pembelajar.

\section{HASIL DAN PEMBAHASAN}

Fullan dan Langworthy (2014) menjelaskan bahwa ada tiga aspek untuk mencapai pembelajaran mendalam yakni sistem ekonomi terbaru, kepemimpinan terbaru dan pedagogis terbaru. Hal tersebut menunjukan bahwa perlu dukungan sistem dan kolaborasi antara ketiganya. Sistem ekonomi terbaru dapat memberikan penghasilan yang memadai untuk bangsa Indonesia; kepemimpinan terbaru artinya seorang pemimpin yang mampu mentransformasi keadaan dengan cepat dan tepat, sedangkan pedagogis terbaru berupa adanya interaksi atau hubungan yang baik antara siswa sebagai pembelajar dan guru sebagai orang yang membelajarkan dan selain itu mampu menggunakan teknologi dalam proses pembelajaran.

Dengan adanya ketiga aspek ini, maka pembelajaran mendalam dapat dilaksanakan dengan baik dan dapat berjalan dengan lancar. Sedangkan untuk mencapai pembelajaran mendalam menurut Fullan dan Langworthy (2014) diperlukan kemitraan pembelajaran antara siswa dan guru, restrukturisasi proses belajar terhadap penciptaan pengetahuan dan penggunaan tujuan dan alat digital dan sumber daya yang memungkinkan dan mempercepat proses pembelajaran mendalam. Langkah-langkah ini dapat menunjang keberhasilan pembelajaran mendalam untuk membentuk karakter siswa sebagai pembelajar dan akan membantu siswa untuk memahami dirinya baik potensi, bakat, minat dan kelebihan maupun kelemahannya.

Prosedur dan strategi yang dilakukan dalam memberikan layanan terkait pembelajaran mendalam dalam lingkup bimbingan dan konseling meliputi identifikasi masalah, diagnosis, prognosis, tindakan remedial atau referal dan evaluasi serta tindak lanjut. Prosedur tersebut harus dilakukan secara berurutan guna mencapai hasil yang maksimal. Hal ini diperlukan untuk memahami siswa, mengembangkan potensi siswa dan mengarahkan potensi yang dimiliki oleh siswa. Sedangkan strategi yang digunakan dalam proses layanan didasarkan sifat masalahnya dan ruang lingkup permasalahan dan pengorganisasiannya. Hal ini meliputi strategi bimbingan melalui kegiatan kelas, layanan khusus yang bersifat suplementer dan proses yang komprehensif melalui kegiatan keseluruhan kurikulum dan masyarakat. Dengan adanya prosedur dan strategi layanan yang jelas maka proses pelaksanaan pembelajaran mendalam untuk membentuk karakter siswa sebagai pembelajar menjadi semakin efektif dan efisien.

Proses pembelajaran mendalam menghargai semua potensi yang dimiliki siswa. Setiap siswa sebagai pembelajar memiliki keunikan dan afinitas masingmasing dalam mengarahkan dirinya sendiri, dan guru memiliki kewenangan untuk mengarahkan dan membelajarkan pada siswa. Adapun langkah untuk membentuk karakter siswa sebagai belajar adalah memahami profil belajar yang unik dan melukis potret dari apa yang memungkinkan setiap siswa menjadi sukses, apresiasi dan keinginan untuk lebih memahami beragam pelajaran sangat penting dan menciptakan lingkungan belajar yang terpusat pada pelajar. Dengan kata lain, proses pembelajaran tidak berfokus pada guru melainkan pada siswa sebagai pembelajar. Adapun yang dilakukan guru adalah memahami karakter, profil, minat, potensi dan kelebihan maupun kekurangan sehingga guru berperan sebagai pembimbing yang mampu mengarahkan siswa sesuai dengan potensi, bakat dan minatnya.

Praktek penerapan proses pembelajaran mendalam meliputi: 1) restrukturisasi pembelajaran siswa dari 
konten kurikuler seperti tujuan atau standar kurikulum nasional lebih menantang dan menarik; 2) memberikan pengalaman nyata dalam menciptakan dan menggunakan pengetahuan baru di dalam maupun luar kelas siswa; 3) mengembangkan dan menilai kunci kemampuan masa depan, seperti

a) Pendidikan karakter, yakni mengedepankan kejujuran, pengaturan diri dan tanggung jawab siswa sebagai pembelajar.

b) Kewarganegaraan, yaitu kepekaan dan menghormati terhadap budaya lain serta keterlibatan aktif dalam menangani isu-isu keberlanjutan.

c) Komunikasi, yakni berkomunikasi secara efektif baik secara lisan maupun tulisan.

d) Berpikir dan pemecahan masalah kritis, yakni dengan berpikir kritis untuk merancang dan mengelola proyek, memecahkan masalah, membuat keputusan yang efektif.

e) Kolaborasi, yakni bekerja dalam tim, keterampilan dalam jejaring sosial, empati dalam bekerja dengan beragam orang lain.

f) Kreativitas dan imajinasi, yang meliputi ekonomi kewirausahaan dan sosial, mengingat dan mengejar ideide baru.

Beberapa langkah dan tugas tersebut adalah bagian dari proses pembelajaran memdalam untuk membentuk karakter siswa. Sedangkan langkah yang dapat dilakukan guna membentuk karakter siswa sebagai pembelajar adalah seperti tampak pada Tabel 1 berikut.

Tabel 1. Membentuk Karakter Siswa sebagai Pembelajar

\begin{tabular}{|c|c|c|}
\hline No & Apa yang dilakukan & Apa yang kita lakukan \\
\hline 1. & Apa yang kita lihat & $\begin{array}{l}\text { - Bukti kelebihan, kedekatan, dan kelemahan dalam } \\
\text { menghindari asumsi dan interpretasi awal. } \\
\text { Pengamatan di sekolah mengenai; } \\
\text { - Wawasan dari orang tua atau pengasuh } \\
\text { - Wawasan dari siswa }\end{array}$ \\
\hline 2. & Apa yang kita pikirkan & $\begin{array}{l}\text { - Mengidentifikasi dan membentuk hipotesis tentang profil } \\
\text { belajar siswa. }\end{array}$ \\
\hline $\begin{array}{l}3 . \\
4 .\end{array}$ & $\begin{array}{l}\text { Apa yang kita lakukan } \\
\text { Apa yang akan kita } \\
\text { rencanakan selanjutnya }\end{array}$ & $\begin{array}{l}\text { - Strategi yang akan diterapkan di sekolah atau dirumah. } \\
\text { - Mengidentifikasi dan mengevaluasi hasil tentang apa } \\
\text { yang akan terjadi setelah kita menerapkan berbagai } \\
\text { langkah tersebut }\end{array}$ \\
\hline
\end{tabular}

Diadaptasi dari Barringer, Mary Dean, dkk. (2010).

Berdasarkan Tabel 1 terlihat bahwa upaya dalam membentuk karakter siswa sebagai pembelajar dengan langkah refleksi diri. Refleksi diri yang dapat dilakukan dengan mengungkapkan apa yang dilihat, dipikirkan, dilakukan dan direncakan selanjutnya. Beberapa hal tersebut bagian dari upaya untuk membentuk karakter siswa sebagai pembelajar.

Upaya lain yang diperlukan dalam membentuk karakter siswa sebagai pembelajar adalah mengembangkan strategi yang diperlukan untuk mendukung mereka sukses dalam mencapai harapan, memanfaatkan kedekatan siswa dapat menguatkan hubungan antara konten dan ketertarikan, membuat pembelajaran lebih relevan dan meningkatkan motivasi siswa untuk terlibat dalam kegiatan ilmiah. Hal ini menjelaskan bahwa guru memiliki peranan penting dalam membangun hubungan yang baik dengan siswa untuk 
dapat mengarahkan, memotivasi dan memberikan pelajaran yang relevan bagi siswa. Upaya tersebut bertujuan untuk membentuk karakter siswa sebagai pembelajar dan mengetahui sejauhmana guru siswa dapat belajar secara mandiri tanpa ada unsur paksaan. Hal ini penting untuk menumbuhkan rasa ingin tahu siswa saat belajar sehingga siswa memiliki tanggungjawab untuk senantiasa belajar.

Pembelajaran adalah proses interaksi antara guru dengan siswa untuk mengembangkan potensi yang dimiliki agar mampu bertahan hidup dan mampu berkontribusi untuk bangsa, negara dan dunia. Pembelajaran akan menjadi kebutuhan bagi siswa ketika menyadari pentingnya ilmu dan belajar. Dengan siswa memahami bahwa belajar adalah kebutuhan maka pembelajaran mendalam akan menciptakan pengetahuan baru dan diarahkan untuk menggunakan pengetahuan baru tersebut. Proses pembelajaran mendalam untuk membentuk karakter siswa sebagai pembelajar seperti tampak pada Gambar 1 berikut.

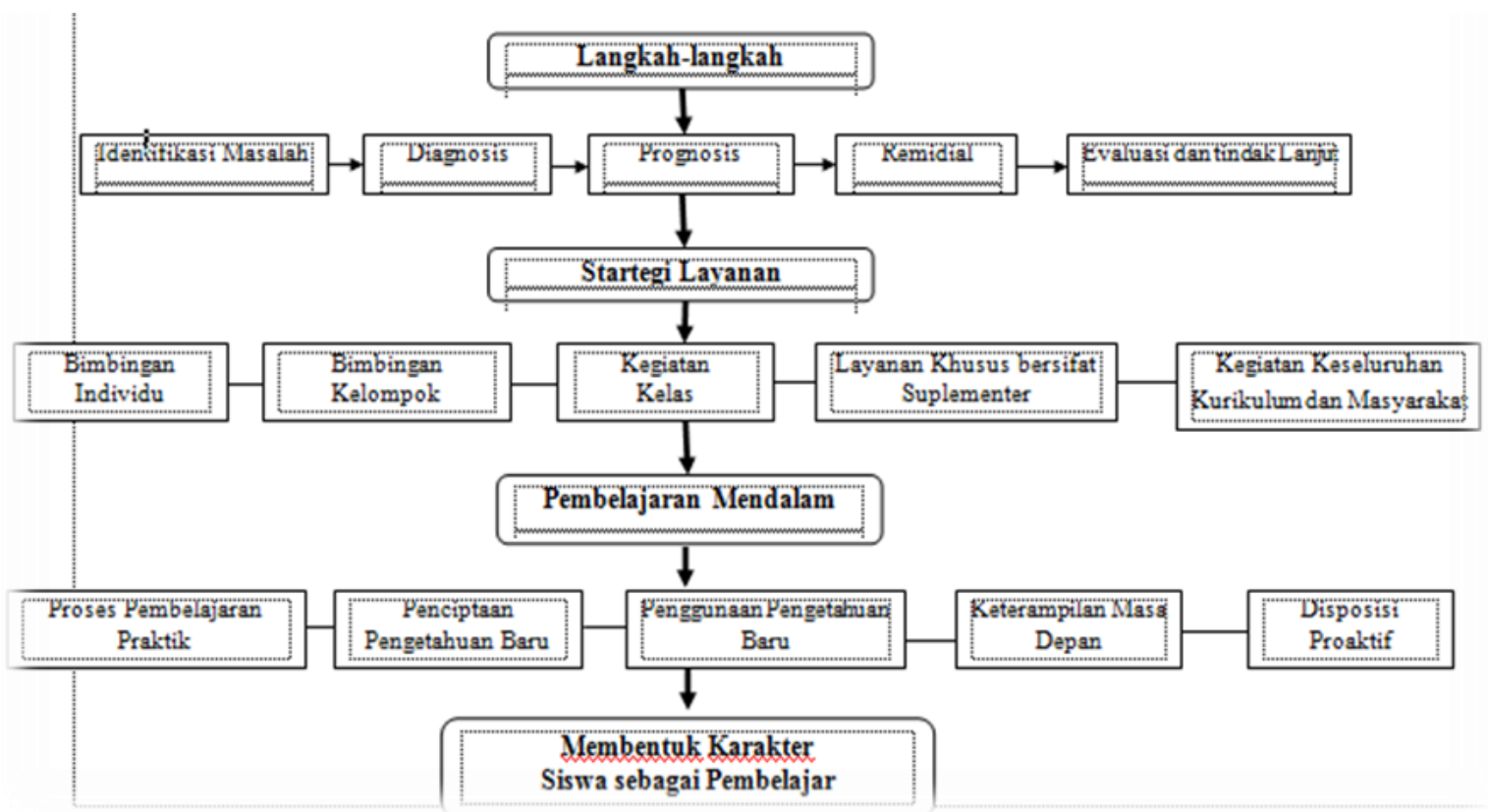

Gambar 1. Proses Pembelajaran Mendalam untuk Membentuk Karakter Siswa sebagai Pembelajar

Pada Gambar 1 tersebut tampak jelas proses pembelajaran mendalam untuk membentuk karakter siswa sebagai pembelajar baik meliputi langkah-langkah yang digunakan guna memilah masalah yang dihadapi siswa, strategi yang digunakan sebagai upaya untuk mencapai keberhasilan belajar dan menerapkan strategi berdasarkan analisis dari masalahnya. Aspek-aspek yang dituju adalah aspek pembelajaran mendalam baik meliputi proses pembelajaran paktik, penciptaan pengetahuan baru, penggunaan pengetahuan baru, keterampilan masa depan dan disposisi proaktif. Kelima aspek yang akan menjadi fokus dari konsep pembelajaran mendalam.

Dengan demikian, pembelajaran mendalam merupakan salah satu strategi untuk membentuk karakter siswa. Khususnya adalah karakter siswa sebagai pembelajar. Karakter ini perlu ditumbuhkan sehingga pembelajaran berfokus pada siswa bukan pada guru. Pembelajaran yang berfokus pada siswa membuat siswa bertanggungjawab terhadap dirinya, sehingga siswa memiliki kesadaran untuk selalu belajar baik untuk 
mengetahui, memahami hal baru dan kemudian mempraktikan pengetahuan yang telah dimilikinya. Kesadaran untuk selalu belajar siswa didasarkan akan potensi, bakat, minat dan kelebihan maupun kekurangannya sehingga siswa melakukannya dengan tanpa paksaan dari siapapun.

\section{SIMPULAN DAN SARAN}

Tiga aspek untuk mencapai pembelajaran mendalam yakni aspek sistem ekonomi, pemimpin dan pedagogisnya. Pembelajaran mendalam meliputi proses pembelajaran praktik, penciptaan pengetahuan baru, penggunaan pengetahuan baru, keterampilan masa depan dan disposisi proaktif.

Pembelajaran mendalam untuk membentuk karakter siswa sebagai pembelajar adalah membantu siswa memahami dirinya sebagai pembelajar untuk meningkatkan pemahaman siswa tentang kelebihan, kelemahan dan afinitasnya; membangun nilai kepercayaan diantara kelompok belajar siswa; dan mampu bersinergi belajar dengan siswa lainnya. Saran untuk penelitian selanjutnya dapat mengeksperimenkan pembelajaran mendalam dalam proses pembelajaran.

\section{DAFTAR PUSTAKA}

Asyhari, A., \& Hartati, R. (2015). Implementasi Pembelajaran Fisika SMA Berbasis Inkuiri Terbimbing Terintegrasi Pendidikan Karakter untuk Meningkatkan Hasil Belajar Siswa pada Materi Cahaya dan Optika. Jurnal Ilmiah Pendidikan Fisika Al-Biruni, 4(1), 37-49.

Diani, R. (2015). Pengembangan Perangkat Pembelajaran Fisika Berbasis Pendidikan Karakter dengan Model Problem Based Instruction. Jurnal Ilmiah Pendidikan Fisika Al-Biruni, 4(2), 241-253. https://doi.org/10.24042/jpifalbiruni. v4i2.96

Eko, A., \& Cahyono, Y. (2017). Pengembangan

Pembelajaran

Perangkat pada Kemampuan Berpikir Kreatif dan Inisiatif Siswa. PHYTAGORAS: Jurnal Pendidikan Matematika, 12(1), 1-11.

Fullan, M., \& Langworthy, M. (2014). A Rich Seam How New Padegogies Find Deep Learning.

Irwandani, I., \& Juariyah, S. (2016). Pengembangan Media Pembelajaran Berupa Komik Fisika Berbantuan Sosial Media Instagram sebagai Alternatif Pembelajaran. Jurnal Ilmiah Pendidikan Fisika Al-Biruni, 5(1), https://doi.org/10.24042/jpifalbiruni. v5i1.103

Irwandani, I., \& Rofiah, S. (2015). Pengaruh Model Pembelajaran Generatif Terhadap Pemahaman Konsep Fisika Pokok Bahasan Bunyi Peserta Didik MTs Al-Hikmah Bandar Lampung. Jurnal Ilmiah Pendidikan Fisika Al-Biruni, 4(2), 165-177.

https://doi.org/10.24042/jpifalbiruni. v4i2.90

Latifah, S. (2015). Pengaruh Model Pembelajaran Kooperatif Tipe Time Token Berbantu Puzzle terhadap Kemampuan Berpikir Kritis Peserta Didik Kelas X pada Materi Gelombang. Jurnal Ilmiah Pendidikan Fisika Al-Biruni, 4(1), 13-23.

Michael, F., \& Maria, L. (2014). A Rich Seam How New Pedagogies Find Deep Learning. Journal of Bodywork and Movement Therapies (Vol. 15). https://doi.org/10.1016/j.jbmt.2011.0 1.017

Nashikhah, M. (2016). Peranan Soft Skill dalam Menumbuhkan Karakter Anak TPA. Tadris: Jurnal Keguruan Dan Ilmu Tarbiyah, 1(1), 33-39. 
Rachmadyanti, P. (2017). Penguatan Pendidikan Karakter Bagi Siswa Sekolah Dasar melalui Kearifan Lokal. JPSD, 3(2), 201-214.

Rahayu, R. (2016). Peningkatan Karakter Tanggung Jawab Siswa SD melalui Penilaian Produk pada Pembelajaran Mind Mapping. Jurnal Konseling GUSJIGANG, 2(1), 97-103.

Rukiyati. (2013). Urgensi Pendidikan Karakter Holistik Komprehensif di Indonesia. Jurnal Pendidikan Karakter, 3(2), 196-203.

Sapulette, M. S., \& Wardana, A. (2016). Peningkatan Karakter Siswa Kelas IV SD Negeri 16 Ambon melalui Pembelajaran PPKN dengan Media Cerita Rakyat. Harmoni Sosial: Jurnal Pendidikan IPS, 3(2), 150165.

Sari, F. K., Farida, F., \& Syazali, M. (2016). Pengembangan Media Pembelajaran (Modul) berbantuan Geogebra Pokok Bahasan Turunan. Al-Jabar: Jurnal Pendidikan Matematika, 7(2), 135-151.

Sukring. (2016). Pendidik dalam Pengembangan Kecerdasan Peserta Didik (Analisis Perspektif Pendidikan Islam ). Tadris: Jurnal Keguruan Dan Ilmu Tarbiyah, 1(1), 69-80.

Suradi. (2017). Pembentukan Karakter Siswa melalui Penerapan Disiplin Tata Tertib Sekolah. BRILIANT: Jurnal Riset Dan Konseptual, 2(4), 522-533. 